\title{
6 Legal legitimacy and the relevance of participatory procedures
}

\author{
Sarah Sorial
}

\subsection{Introduction}

The relevance of certain forms of participation for legitimacy is well documented in the extensive social sciences literature. ${ }^{1}$ This empirical research demonstrates the importance of having a 'voice' in legal proceedings, or an opportunity to present one's case, and the importance of being treated with respect by legal officials. This research adds substantive weight to the theoretical arguments that procedural justice is intrinsically valuable because of the way it respects individual dignity and autonomy, ${ }^{2}$ and increases people's willingness to comply and cooperate with authorities (Meyerson 2015a, p. 26; 2015b, p. 76).

In this chapter, I draw on procedural theories of law and democracy ${ }^{3}$ to develop a normative account of why participation matters for legitimacy and compliance with the law. I suggest that this normative account can help explain the issues of authority and compliance in ways that are sensitive to the nature of law in democracies, and with laypersons' intuitions about why participation matters. ${ }^{4}$ In particular, I demonstrate the ways in which the relationship between the citizen and the state is more complex and less linear than it is characterised and described in some of the psychological literature. In this respect, this chapter builds on the 'relational' aspect of legitimacy identified by Meyerson (2015a, 2015 b), and on the idea of 'legitimacy as dialogue' developed by Bottoms and Tankebe (2012, p. 159).

In Section 6.2, I give an account of the empirical evidence, which is concerned with people's perceptions of legitimacy. I suggest that these descriptive claims about why people accept the authority of law and comply with it represent the relationship between the citizen and the state as a 'top down' relationship, rather than a complex dialogical and relational one. In Section 6.3 I give an account of procedural theories of legitimation, to demonstrate two things: first, the ways in which participation shifts the locus of authority and law-making from the state to the citizenry. Second, the ways in which this shift from government to citizens enables us to give a different account of legitimacy: namely, that people should accept the authority of law issuing and law applying institutions and should comply with legal norms if these procedural processes are in place. I refer again to some of the empirical evidence to substantiate this claim, and to suggest

DOI: $10.4324 / 9780429317248-9$ 


\section{Sarah Sorial}

a different theoretical model for interpreting this evidence. ${ }^{5}$ In Section 6.4, I use this theoretical model to explain the relationship between procedural fairness and legitimacy in the context of the criminal trial, focusing on the opportunity to be heard in one's own defence. Finally, I discuss some policy implications and respond to potential objections in Section 6.5.

\subsection{Participation and legitimacy: the empirical evidence}

In his ground-breaking book, Why People Obey the Law, Tom Tyler distinguishes between instrumental and normative reasons for obedience to law (Tyler 1990, p. 3). He further breaks down normative reasons into two categories: personal morality (consisting of people's beliefs about how they should act) and legitimacy (referring to people's perceptions as to whether law enforcement officials rightly have authority over them, i.e. descriptive legitimacy). In a series of surveys asking people questions about their recent contacts with the police or the courts, their reactions to those contacts, and their subsequent behaviour, Tyler concludes that people comply with the law when they perceive that legal authorities are legitimate and that their actions are generally fair (Tyler 1990, p. 6). These findings lead Tyler to prioritise normative compliance over instrumental compliance, and within normative compliance, to prioritise legitimacy. Interestingly, it was the perceived procedural fairness of law enforcement authorities, rather than the perceived fairness of the outcome, that was most significant for subsequent compliance.

There has been a significant amount of further research, which confirms these initial findings. Legal institutions and authorities are deemed legitimate when people have trust and confidence that legal authorities are honest (Tyler \& Jackson 2014 , p. 78). This causes people to 'authorise' the legal authority to dictate appropriate behaviour because they trust and have confidence that legal authorities are honest and act in ways that have citizens' best interests at heart (Tyler \& Jackson 2013, pp. 87-88; 2014, p. 78). The connection between legitimacy and compliance with the law is based on the theoretical consideration that people are able to transcend their short-term self-interest, including getting the outcome they want, to take actions that are consistent with their conceptions of what is right and appropriate (Tyler \& Jackson 2014, p. 81).

Procedural justice emerges as the key criterion for conferring legitimacy and securing compliance in the descriptive sense. It refers to whether people perceive that authoritative officials - police and court officers - use their power in fair, just, and neutral ways. In these descriptive accounts, procedural justice is understood in four main ways. First, people want an opportunity to explain their situation or tell their side of the story in a conflict (Jackson \& Tyler 2014, p. 81). Second, people value neutrality, which means they expect that the decisions that are made are based on consistently applied legal principles and the facts of the case, and not on personal opinion or biases. Related to this, people expect processes to be transparent and for officials to be open about how decisions are being made. This facilitates the belief that decision-making procedures are neutral and made in 
an objective way (p. 82). Third, people are sensitive to whether they are treated with dignity and politeness, and whether their rights as citizens are respected: 'people believe that they are entitled to treatment with respect and react very negatively to dismissive or demeaning interpersonal treatment' (Tyler \& Jackson 2013 , p. 82). Finally, people focus on cues that communicate the intentions and characters of the authorities with whom they are dealing:

authorities communicate this type of concern when they listen to people's accounts and explain or justify their actions in ways that show an awareness of and sensitivity to people's needs and concerns.

Tyler and Jackson conclude:

The key point about procedural justice is that being treated fairly communicates value and respect within a group, which fosters compliance with group rules, promotes cooperation, and leads to identification and engagement with the group. Hence procedural justice promotes legitimacy and advances each of the three goals outlined: compliance, cooperation, and engagement.

While there is generally broad agreement about the importance of legal legitimacy in the social sciences literature, there is no accepted definition of legitimacy more generally (Jackson \& Gau 2015, p. 49). Moreover, given the important role played by the concept in the empirical literature, a number of researchers have highlighted the need to re-examine and expand the ways in which legitimacy is conceived (Tyler \& Jackson 2013, p. 87; Bottoms \& Tankebe 2012, p. 119). Jackson and Tyler, for example, have argued that it is important to ask why legitimacy influences behaviour, in the sense that it achieves compliance with legal norms (Tyler \& Jackson 2013, p. 87 supra note 39). They offer three reasons that potentially explain why legitimacy influences behaviour: psychological reasons associated with perceived duties to obey institutions, the trust and confidence people have in authorities, and the extent to which legal norms 'morally align' with peoples' values.

According to Tyler and Jackson, legitimacy is a motivation to act based on positive and intentional beliefs about the right to power and influence (Tyler \& Jackson 2013, p. 87). When one recognises the legitimacy of an institution, one believes that the institution has the right to proscribe and enforce appropriate behaviour, and that one has a corresponding duty to obey those proscriptions. Kelman and Hamilton call this 'authorisation' to reflect the idea that the person has authorised the authority to determine the appropriate behaviour in some contexts, and then feels obligated to follow those directives or norms (Kelman \& Hamilton 1989, p. 16). This is referred to as 'internalisation' where the norms become part of an individual's motive system, guiding behaviour in the appropriate way, even when no authority exists (Hoffman 1977, pp. 55-57). 


\section{Sarah Sorial}

The second reason legitimacy influences behaviour is the trust and confidence that people have in authorities and legal officers. Jackson and Gau define trust as the subjective judgement that a person (the trustor) makes about the likelihood of another person (the trustee) following through with an expected action. This requires the trustor to draw on a variety of sources, such as past experience with the trustee, personal relationships, and intuitive or 'gut' responses when deciding on the level of trust to place in the person (Jackson \& Gau 2015, p. 52). For example, with respect to law enforcement officials such as the police, this definition of trust refers to people's expectations regarding future behaviour from police officers under conditions of uncertainty (Jackson \& Gau 2015, p. 53). A person can never be sure that the police will respond promptly if called, that she will be treated with respect, and that she will be heard. However, the person may have formed a judgement about the intentions and the capacity of the police officers to respond appropriately with respect to their social role, based on prior contact with law enforcement officials, and these judgements will shape the individual's willingness to accept uncertainty and vulnerability, by perhaps coming to the police with information about a crime (Jackson \& Gau 2015, p. 53).

The third reason why legitimacy influences behaviour is because of identification and a sense of shared values or 'moral alignment'. According to Tyler and Jackson:

Pride and status encourages identification with the group, and identity judgments then shape attitudes, values and cooperative behaviour. Pride, respect, and group identification-activated by the use of fair procedures-may consequently encourage not just a felt obligation to obey the rules of the group, but also a (connected) sense of shared moral values and purpose.

(Tyler \& Jackson 2013, p. 92, supra note 39)

Moral alignment is considered a constitutive element of legitimacy because it justifies the power and authority of legal officials in the eyes of the community (Tyler \& Jackson 2013 p. 92, supra note 39). Finally, these features shape law-abiding behaviour because people tend to cooperate, comply, and accept the authority of the state and its use of force when they believe that the state has rightful authority, when they trust the state and its officials, and when they identify with its goals and moral values. If these conditions of legitimacy are met, then it is likely that people will accept that they have a duty to obey the law.

While I do not contest the importance of identification, trust, and fair treatment for the purposes of achieving compliance with legal norms, I suggest that this account of legitimacy fails to fully appreciate why participation might contribute to legitimacy for reasons aside from trust and why it matters for the purposes of identification. These reasons may have more to do with the nature of legitimacy in democratic societies, where participatory procedures confer objective legitimacy on governments. As such, the empirical research continues to adopt a 'top down' approach regarding the relationship between citizens and 
the state, rather than a 'bottom up' or dialogical relationship. For example, Tyler and Jackson rely on a traditional model of social regulation, where legal authority is centralised in elites, who issue legal norms and make legal decisions. They explain,

Legal elites expect the public to accept their authority and comply with the law; legitimacy as authorisation and perceived obligation means that people allow legal authorities to prescribe their behaviour when enforcing rules. People obey the law because they believe that legal authorities have the right to dictate appropriate behaviour.

(Tyler \& Jackson 2014, p. 78)

But why do legal elites expect this level of compliance and why and how do people authorise them to make legal norms? While it is the case that people obey the law because they accept the law's authority, they do not blindly follow it or simply do what authorities command because the authority says so. The language of lawmakers having 'authority' over 'subordinates' assumes a disconnect between those who govern, issue directives, and make decisions, and those who are governed and obey those directives. It assumes that citizens come to identify with the law for reasons that have more to do with trust in legal authorities, than because of the existence of participatory procedures. The more benevolent and trustworthy the officials are, the more their power is recognised, and their orders complied with. There is very little to suggest that citizens also have significant power and protections in legal processes (although this is implied by the evidence), and that they might accept the legitimacy of the law because they had some involvement in how that law or legal decision was made, by virtue of the existence of participatory procedures. The nature and extent of this involvement will vary depending on the kind of issue under consideration and a person's level of interest, ability, and engagement, to name a few. What matters, however, is that in various fora appropriate participatory procedures are in place, to enable appropriate levels of participation in legal decision-making.

In the following section, I draw on procedural models of law and democracy to offer a normative account of legitimacy. I suggest that legitimacy is conferred in the normative sense by virtue of an ongoing relationship and dialogue between citizens and the state, where citizens participate in various ways in issuing authority or in devising the norms that will bind them. This participation occurs in a number of different contexts, including in elections, in law-making, and in the context of a trial or other kind of hearing (such as a tribunal or a commission inquiry). Of course, the level and kind of participation in these different fora will vary, but my claim is that the existence of participatory procedures, no matter their form, confers legitimacy in a normative sense, and brings about compliance with the law. This procedural model is better able to respond to the unique features of legitimacy in democratic societies, a feature that is somewhat absent from the social sciences and traditional jurisprudential literature. 


\section{Sarah Sorial}

\subsection{Procedural theories of democracy and law}

The ideal of democracy views government action as a collective action. It is the actions of the community, achieved through various procedures that determine the preferences or views of its members. Procedural theories of legitimacy focus on how the directives of an authority are arrived at and how an individual might contribute to the outcome. For example, a procedural theory might judge whether the process was deliberative, fair, or public (Hershovitz 2003, p. 212). Lon Fuller, perhaps one of the few legal theorists to take seriously this connection between democracy and law, and between participation and legitimacy, argued that adjudication, contract, and elections are three ways of reaching decisions, settling disputes, and regulating relations between people. The characteristic feature of these different kinds of social ordering 'lies in the manner in which the affected party participates in the decision reached' (Fuller 1978, p. 363). Ideally, each of these arrangements requires that certain background conditions be met, or the existence of certain procedures. In the case of elections, it requires an intelligent and fully informed electorate, an active interest in the issues being discussed, candid discussion of the issues in public debate, and widespread participation, conditions that Fuller thought were 'scarcely ever realised in practice' (p. 364).

Adjudication also depends on various procedures that provide the affected parties with an opportunity to participate in the decision, by way of presenting evidence and reasoned arguments. However, it differs from participation in democratic politics because it demands a higher standard of reasoning, both in terms of the arguments being presented by the parties, and the judgement that is reached by the impartial adjudicator:

adjudication is ... a device which gives formal and institutional expression to the influence of reasoned argument in human affairs. As such it assumes a burden of rationality not borne by any other form of social ordering.

(Fuller 1978, p. 367)

The process of adjudication becomes a farce should the decision that is reached make no pretence to rationality.

Elections, by contrast, are often decided by the preferences of voters who are 'emotional, inarticulate, and not subject to rational defense ... the will of the majority controls, not because it is right, but-well, because it is the will of the majority' (Fuller 1978, p. 367). Despite his scepticism about the reasoning ability of the electorate, Fuller nevertheless offered an account of law as a cooperative venture between rulers and ruled, requiring reciprocal obligations of mutual respect. Fuller's account of law and legitimacy is capable of application to liberal democracies in general and is consistent with the moral and political assumptions underpinning them.

As Allan argues, Fuller's 'internal morality' can be interpreted as a demanding ideal of due process of law that, when fully elaborated, imposes an obligation 
on the government to defend every coercive act on the grounds that it in the interests of all. The rule of law is essentially a procedural ideal, because the common good or the interests of all is left open for public debate, and any decision reached by the government needs to be rationally defended with reference to the needs and interests of the community as a whole (Allan 2001, p. 75). When the state's demands are understood as making an appeal to the general good, 'the citizen's moral judgment is inextricably engaged in the identification of law. He is enjoined by the constitution itself' (p. 76). Closely connected with this relationship between the citizen and the state, and the rule of law, is a distinctive view of procedural fairness that reflects the sense in which the government, under the rule of law, is required to enter into a dialogue with citizens. The rule of law demands an opportunity for consultation with relevant officials.

Fuller's theory does not, however, elaborate on this relationship or dialogue between the citizen and the state. ${ }^{6}$ More recent procedural theories of democracy and law give a richer, and less cynical account of public reason and of the specific procedures, which enable such a dialogue. For example, Habermas' procedural model of legal legitimacy shifts the locus of legislative and decision-making power from the formal institutions of the state and locates it in the communications of an unsubverted public sphere. The public sphere is, in turn, tied to the 'associational network of a liberal civil society and gains support from the core private spheres of the lifeworlds' (Habermas 1998, p. 18). This model also shifts the normative expectations from the level of the actors' qualities and competences to the forms or procedures of communication in which opinion-formation can develop and interact with the formal organs of the state (p. 18).

For Habermas, legal legitimacy is achieved by way of various participatory procedures or in the communicative networks of public spheres, which can include anything from a town-hall meeting, online discussion fora, media discussions, and so on. Participation is essentially a discursive activity, requiring people to present reasons and arguments for particular policies, ones that are based not only on their own self-interest, but also in the interests of their community more broadly. This participation takes place in a variety of different fora, including public opinion-formation, institutionalised elections, and legislative decisions. These fora are categorised in terms of informal and formal processes of deliberation, and together form Habermas' two-track model of deliberative democracy so that,

deliberative politics thus lives off the interplay between democratically institutionalised will-formation and informal opinion-formation. It cannot rely solely on the channels of procedurally regulated deliberation and decision-making.

(Habermas 1998, p. 308)

The two tracks of deliberation perform two different functions.

Informal communication in the public sphere is disorganised, anarchic, and uncoordinated. It provides an unregulated space for detecting new problems, 
bringing them to public awareness without the use of specialised language, and suggesting ways to address them,

because the general public sphere is 'unconstrained' in the sense that its channels of communication are not regulated by procedures, it is better suited for the 'struggle over needs' and their interpretation.

(Habermas 1998, p. 314)

In this way, 'the communicative structures of the public sphere constitute a farflung network of sensors that react to the pressure of society-wide problems and stimulate influential opinions' (Habermas 1998, p. 300). The public space is founded on a network of associations that 'specialise ... in discovering issues relevant for all society, contributing possible solutions to problems, interpreting values, producing good reasons, and invalidating others (p. 485). Only after such a public struggle for recognition of issues as political can the responsible political authorities take up the proposals, put them on a parliamentary agenda and then legislate and make binding decisions in relation to them. This is referred to as the formal track of the legislative process.

The formal track of deliberative decision-making is how informal deliberation is made into positive law by conventional political institutions and the organs of the state. Formal political processes also include elections and legislatures, and the formal organs of the state include courts. The function of these institutions is to assess ideas, solutions, and make authoritative decisions that will be accepted by those affected. Habermas (1998) explains that these formal political processes rely on the informal public sphere when devising policies and laws:

The operative meaning of these regulations consists less in discovering and identifying problems than in dealing with them; it has less to do with becoming sensitive to new ways of looking at problems than with justifying the selection of a problem and the choice among competing proposals for solving it. The publics of parliamentary bodies are structured predominantly as a context of justification. These bodies rely not only on the administration's preparatory work and further processing but also on the context of discovery provided by a procedurally unregulated public sphere that is borne by the general public of citizens.

(Habermas 1998, p. 307)

This two-track system displaces the principal locus of participation from formal political institutions to the informal public sphere and is intended to explain how legal legitimacy ought to be achieved, with respect to both the issues of authority and compliance. It describes the kinds of communication necessary between the citizen and the state, and the various procedures that mediate this dialogue.

Why do these participatory procedures produce legitimacy (or why can they give us a more adequate answer to the issues of authority and compliance?). First, 
participatory procedures ensure that all those affected by an issue have some input into how that issue is addressed. They can ensure that all aspects of the issue have been identified and that all available evidence is presented. The resulting law issued by the legislature is thus considered legitimate because citizens have had the opportunity to participate in and formulate the law that will ultimately bind them. The law has the authority it does because it was achieved using a 'bottom up' process, rather than a 'top down' one.

Of course, it will not be the case that everyone who participated in the discussion will agree with the decision that is eventually reached. Nevertheless, they are still bound to comply with the law because the procedures were democratic, transparent, and based on good reasons, even though the final decision is contested. As Waldron puts it,

When something is enacted as law or as a source of law, I believe it makes on us a demand not to immediately disparage it, or think of ways of nullifying it or getting around it ... it is a demand for a certain sort of recognition and ... respect-that this, for the time being, is what the community has come up with and that it should not be ignored or disparaged because some of us propose, when we can, to repeal it.

(Waldron 2001, p. 100)

Second, participatory procedures ensure that all citizens are treated with equal concern and respect. They presuppose that citizens are autonomous, selfdetermining agents, capable of organising their own affairs, and pursuing their own interests and conceptions of the good. As such, participatory procedures assume that citizens not only have the ability to participate in political debate but that they would want some say in how decisions that affect them are made. As Hershovitz explains,

since governments play a pervasive role in organising our lives, denying people the opportunity to participate in the process of government closes off opportunities to organise one's life autonomously. Democratic procedures afford people opportunities to participate in life-defining decisions.

(Hershovitz 2003, p. 214)

So, while features like identification and trust in legal officials are important for people's perceptions of legitimacy, as the psychological literature describes, it is participatory procedures that confer legitimacy and bring about compliance with the law. Moreover, identification with one's community and the establishment of shared values presupposes participation, insofar as it is the community itself that comes together to deliberate about what those shared values are and how they can be actualised in law. While elites might be responsible for shaping the actual law, this is not something that they impose from the 'top', onto 'subordinates' who then obey. As I have suggested, in a democracy, it is the people who ought to decide what is best for themselves and their communities, who ought 
to identify various issues that need to be addressed, and who ought to propose various ways of solving them. It is the citizens who should give reasons to one another to support one course of action over another, and it is the people who are affected by a particular issue who are best placed to make recommendations about how that issue should be addressed.

Again, the empirical evidence bears out these normative claims. Tyler and Jackson note that studies of long-term approaches to creating social order indicate the importance of creating viable communities, ones where people have a shared attitude, which in turn motivates engagement. If people are encouraged to engage in their communities socially and economically, they build social capital. They come to know others and how to work with them when problems arise in the community; they build trust in others and develop the belief that others can and will act collectively when issues arise (Tyler \& Jackson 2014, p. 80).

Tyler and Jackson seek to explore whether such engagement can be enabled and facilitated by legal authorities: whether 'the legal system can develop policies and practices that generate supportive attitudes and values that enhance communities' $(2014$, p. 80 ). They find that the exercise of authority by way of fair processes and decision-making strengthens the social bonds between individuals and communities. People come to identify with the group that the authority represents and internalise the belief that they should follow the rules of the group and the laws that are issued by it. They find that legal institutions and authorities play a crucial role in fostering the identity needed to establish legitimacy, and in forging the social and collective bonds of a community (p. 80).

Using a proceduralist model of democracy and law, it is possible to interpret these findings using a 'bottom up' approach to legitimacy: it is the people themselves who come together to identify and help solve various social coordination problems, thereby fostering identification and solidarity with a group, a sense of shared values and respect for one another. Social elites and legal officers might then play a role in actualising a particular decision, perhaps by creating legislation and enforcing it. The relationship between legal authorities and communities in democratic societies is thus more complicated and less linear than Tyler and Jackson suggest. People do not accept the legitimacy of law because of the benevolence of legal institutions and authorities, but they ought to by virtue of the existence of various participatory procedures. This is a dialogical and discursive process, involving deliberation between citizens themselves, and between citizens and their elected representatives. Citizens thus should accept the law as legitimate and should consider themselves bound to obey it (even if they do not agree with it) because they played some part in shaping it. In the following section, I use this procedural account of legitimacy to explain the importance of procedural fairness in the context of a criminal trial, focusing on the opportunity to be heard in one's own defence. 


\subsection{The opportunity to be heard in one's own defence and legitimacy}

There are three significant relations between participation and legitimacy in the context of a criminal trial. First, giving the accused the opportunity to be heard in his or her defence may lead the accused to accept the decision, even if it does not go in his or her favour. Second, publicly presenting reasons for a decision means a political order is recognised as right and just, and thus as deserving of legitimacy. Third, participation extends to other actors in the criminal trial, such as members of a jury, and the participation of these various actors contributes to legitimacy in different ways.

Of course, there are vast differences between the kind of participation that occurs in the informal deliberative spheres and in a formal trial. In the public sphere, participation can take the form of deliberating over a public policy issue at a town-hall meeting, protesting, writing to elected representatives or to newspapers, making submissions to parliamentary inquiries, and so on. These kinds of participation are, to greater or lesser degrees, unconstrained by various rules of order, and they are governed by various and differing procedures. For example, a town-hall meeting is likely to have more formal procedures that require participants to take turns speaking, and are regulated by a chairperson, whereas a protest march may have multiple deliberative sites and be largely unregulated, in terms of what people say and how they say it. These forms of participation are also open to all persons who are interested or who have a stake.

Participation in an adjudicative process differs in some fundamental ways. It is not open to anyone to participate in a trial (although the public nature of trials means that anyone can attend one). Only the parties affected are represented and allowed to present their cases; how they present evidence is subject to strict rules of procedure. Moreover, the kind of reason-giving in a trial is typically subject to higher standards than one would expect to find in the public sphere. A further distinctive feature of the procedural aspects of the rule of law is the requirement that individuals facing the imposition of some kind of penalty by the government must have a right to make legal arguments about the bearing of evidence and the legal norms relevant to the case. In doing so, participants are given an opportunity to affect a legal outcome, and this contributes to making a legal decision legitimate (Solum 2004, p. 274).

Despite these differences in the kinds of participation in different contexts, some key features of participation remain relevant across all deliberative contexts. First, the person whose interests are at issue is entitled to be heard, should be able to give evidence and make arguments for his or her position or case. Second, in each context, these arguments should be given due consideration and incorporated in the final decision. Third, all decisions reached need to be supported with good reasons that all participants can accept, even if the person does not get the outcome she was hoping for. And finally, this participation is crucial for legitimacy across these different deliberative spheres. ${ }^{7}$ 


\section{Sarah Sorial}

Another causal factor to achieving legitimacy in the context of a trial is reasongiving by legal officials. Adjudication is thus not merely a process of reaching the correct result, consistent with appropriate legal standards, but more importantly, an attempt to justify that result to both parties (Allan 2001, p. 79). Lucas further argues that a principal purpose of the rules of natural justice, which define a 'fair hearing', is to enable a person to identify with the decision-making process and 'make it manifest to anyone disappointed at the outcome that we were solicitous of his interests and did not reach an adverse decision lightly or wantonly, but only for good reason and with evident reluctance' (Lucas 1980, p. 97).

Participation in one's own trial, in the form of being given an opportunity to be heard, may lead the accused to accept the decision and comply with the law. However, the public nature of a trial and the close scrutiny and argumentation about the legal norms at issue can achieve legitimacy more generally through widespread recognition of the courts as just institutions. Decisionmaking is, as Galligan puts it, an 'unruly process', one that requires judges and lawyers to try to make sense of the law as a whole, including not only the law and the evidence, but also in relation to the norms and standards, values, and beliefs operating in a complex social world (Galligan 1997, p. 65). It is, then, much more than the simple application of relevant laws to the facts of particular cases; because decision-making occurs in this space between legal norms, the facts of the case, and complex social circumstances, the procedures that are best suited for this purpose are ones that encourage inquiry, argument, and deliberation. They should reflect the fact that different ways of interpreting an issue are available, and that interpreting evidence and evaluating facts are open processes.

Subjecting legal norms to such intense and public scrutiny achieves widespread recognition of the authority of the courts. As Ho puts it, the trial is itself a process of public justification. Publicity is understood primarily in two ways: first, the grounds the executive has for a conviction must be presented in a forum in which the citizenry have right of access-justice must be seen to be done; and second, the reasons given for a guilty verdict must aim at public acceptability, meaning that reasonable citizens must be able to accept the reasons as sound and sufficient grounds for a conviction (Ho 2010, p. 53). The kind of debate that occurs in a courtroom and the accessibility of these arguments by the citizenry ought to achieve widespread legitimacy, insofar as people should come to recognise the authority of the courts and respect their decisions.

Participation in this context is not direct participation, because those who are not part of the proceedings do not have a right to make submissions or arguments. However, they indirectly participate in having access to the court proceedings (any person can, for example, attend court) or they can access the arguments that are made, and the courts' reasoning for its decisions, and can participate in an ongoing public dialogue about those issues, where appropriate. In this respect, the courtroom forms part of a broader political and legal dialogue, in some cases, promoting public debate about various legal issues, which may lead to law reform in other spheres. 
Finally, participation in criminal trials also extends to the role of juries and promotes and achieves legitimacy in various ways. Notwithstanding some of the problems with juries, as an ideal, trial by jury has deep democratic roots- to be tried by a jury is to be tried by one's own peers, and hence to be judged by the norms and standards of one's community. Jury deliberation, the process of discussion, argumentation, and reasoning by a representative group of citizens in search of a collective judgement of a fellow citizen, has been described as the 'crucible of democracy' and it has been said that 'the democratic theory of law would favour the retention of trial by jury as the means whereby the people play a direct, contributory part in the application of the law' (Ho 2010, p. 253). The jury is one occasion where citizens participate in legal decision-making, and there have been occasions where a jury has refused to apply a norm that it deems oppressive, and hence, illegitimate. ${ }^{8}$

\subsection{Objections and policy implications}

There are at least two potential objections to this normative account that bear mentioning. First, actual participation in public deliberation falls significantly short of the ideal as represented here. A great deal of law is made by political elites without adequate participation by those affected, so in the absence of genuine participation, it is necessary that people come to trust legal officials to achieve legal legitimacy. Second, participation in one's own trial is also overstated. The increasing frequency of plea bargaining may mean the right to be heard in one's own defence is forfeited in some criminal trials, and this does not appear to affect the legitimacy of decisions or affect whether people ought to comply with the law.

With respect to the first claim, while it is the case that actual law-making is made by legal elites, this is often in response to issues that have been identified in the public sphere as requiring legal responses, at least more often than not. For example, law reform in areas such as domestic violence, sexual assault and sexual harassment have occurred because women have identified these as serious social and political issues (first in the informal public sphere), and put these issues on the legislative agenda. Participation at the informal levels thus can and does influence the legislative agenda. Provided these participatory mechanisms are in place, it should lead to legitimacy and compliance with the law.

At a practical level, I concede that not every person affected by an issue will participate in law-making. It might be sufficient for the purposes of legitimacy that a wide range of views are represented in deliberation and are reflected in the final decision reached. This weakens the requirement that every person affected by an issue should participate in dialogue for the law or decision to be deemed legitimate (for this would be impractical, and time and resource intensive), but it does not affect that normative claim that so long as various participatory procedures are in place, legitimacy and compliance with the law ought to be achieved.

There are also persistent issues of equality of access, especially for people who are socially marginalised or less well-educated, and so may not be able to genuinely participate in dialogue. This is a more intractable and complex problem, and 


\section{Sarah Sorial}

a full examination of these issues is outside the scope of this chapter. Suffice it to say that large-scale inequalities in a society will distort deliberative exchanges, and may over time, undermine or weaken the legitimacy of authorities (such as governments or law enforcement officials) and compliance with the law.

The second concern is that participation in the context of legal trials is also overstated. Arlie Loughnan, for example, has argued that the rise of institutional practices such as plea bargaining or charge negotiation suggest that the criminal trial plays a 'symbolic role that far outstrips its practical significance' (Loughnan 2010 , p. 536). Dubber goes further, arguing that the prevalence of plea bargaining, especially in the American criminal justice system is symptomatic of a crisis in the modern criminal process, where informal and non-public arrangements are increasingly replacing public trials in the imposition of punishment (1996-1997, p. 547).

At a descriptive level, there is an increased tendency to forfeit one's right to be heard and forgo criminal trials in favour of plea bargaining. There are also good practical reasons for this, including increased efficiency, caseload management, and to spare victims the trauma of a trial. However, given the normative account I have defended, the increased use of practices such as plea bargaining should be of concern. If participation matters for legitimacy, perhaps over time, these institutional practices will erode the legitimacy of authorities, or undermine legal decisions.

Finally, this account of the relevance of participation has some important policy implications for both the criminal trial and for policing. It suggests that despite the costs and time resources associated with trials, the right to a fair hearing and an opportunity to defend oneself during a trial are important, and ought not be eroded or replaced by plea bargaining and charge negotiation. The trial provides an important opportunity for participation, which is not only important for legitimacy of outcomes in particular cases, but also for legitimacy of law more broadly. The account of participation presented here also indicates the importance of involving and consulting with communities in the context of policing. It is likely that communities are best placed to understand their needs and will be more likely to accept police decisions and cooperate with police if they have the opportunity to participate in developing the policies that are to govern them.

I have argued that participatory procedures are relevant to answering the complex questions posed by the issue of legitimacy — what gives institutions and legal officials the authority they have to make and issue legal norms and why should we comply with these norms? I have focussed on the relational and dialogical features of participation, in order to demonstrate that the relationship between the citizen and the state is more complex and less linear than conceived in traditional jurisprudential debates and in the empirical literature; that the dialogue is an ongoing one; and that it occurs across multiple deliberative spaces, including in courtrooms. If this account of the relevance of participatory procedures to achieving legitimacy is convincing, it might help explain the damage that can be done to our legal institutions when the principle of participation is undermined, through practices such as the increasing use of non-public plea bargaining. It can 
also explain why some communities do not cooperate or trust police and other law enforcement bodies, and it can also provide ways of fostering this trust and identification through dialogical means.

\section{Notes}

1 See for example, Tyler $(1990,2006)$, Sunshine and Tyler (2003), Tyler and Fagan (2008), Tyler and Jackson (2014), Jackson et.al. (2012), and Murphy Bradford, and Jackson (2016).

2 See for example, Waldron (2011), Duff, Farmer, Marshall, and Tadros (2007).

3 In particular, I draw on the work of Lon Fuller (1978) and Habermas (1996).

4 See for example, Jeremy Waldron's comments that the 'dirty little secret' of modern jurisprudence is that it is uncomfortable with democracy (Waldron $2001 \mathrm{pp}$. 8-9), and his comments that when lay persons talk of the 'rule of law', they are not referring to the form of law, but to procedures. (Supra note 2, p. 5 ).

5 For example, I use this account to offer a different interpretation of Tyler and Jackson's (2014) findings.

6 See for example, Allan's comments that Fuller's account of law is too spartan and 'his commitment to the values of liberal democracy overly self-restrained.' (Allan 2001, p. 73). See also Waldron's criticisms in 'The Rule of Law and the Importance of Procedure.' (Waldron 2011, pp. 10-11).

7 See also Galligan (1997, pp. 130-132).

8 Consider, for example, some instances of 'jury nullification' where juries have ignored the law to acquit defendants who are otherwise guilty at law because they perceive the application of the law in the circumstances to be unjust. In the case of $R \vee R 28$ SASR 321 (1981), a woman was initially convicted of murder for killing her violent and abusive husband because the trial judge refused to direct the jury on the issue of provocation (traditionally a defence used by men who kill their partners for reasons of separation or suspected infidelity). On appeal, a second jury acquitted the woman. Or consider the more recent US trial of William Lynch, charged with felony assault for attacking an elderly priest who had abused him as a child. He was also acquitted by a jury despite being guilty at law. See https://nswcourts.com.au/articles/juries-dont-always-follow-the-law/

\section{References}

Allan, TRS 2001, Constitutional justice, Oxford University Press, Clarendon.

Bottoms, A \& Tankebe, J 2012, 'Beyond procedural justice: a dialogic approach to legitimacy in criminal justice', Journal of Criminal Law and Criminology, vol. 102, no. 1, pp. 119-170.

Dubber, M 1996-7, 'American plea bargains, German law judges and the crisis of criminal procedure', Stanford Law Review, vol. 49, no. 3, pp. 547-605.

Duff, A, Farmer, L, Marshall, S \& Tadros, V 2007, The trial on trial, vol. 3, Hart Publishing, Oxford.

Fuller, L 1978, 'The forms and limits of adjudication', Harvard Law Review, vol. 92, no. 2, pp. 353-409.

Galligan, DJ 1997, Due process and fair procedures: a study of administrative procedures, Published to Oxford Scholarship Online, viewed 18/11/2019, https://www.oxf ordscholarship.com/view/10.1093/acprof:oso/9780198256762.001.0001/ac prof-9780198256762

Habermas, J 1996, Between facts and norms, MIT Press, Cambridge, MA. 
Habermas, J 1998, 'Paradigms of law', in M Rosenfeld and A Arato (eds), Habermas on law and democracy: critical exchanges, University of California Press, Berkeley, CA.

Hershovitz, S 2003, 'Legitimacy, democracy, and Razian authority', Legal Theory, vol. 9 , no. 3 , pp. 201-220.

Ho, HL 2010, 'Liberalism and the criminal trial', Sydney Law Review, vol. 32, no. 2, pp. 269-287.

Hoffman, M 1977, Empathy and moral development, Cambridge University Press, New York.

Jackson, J, Bradford, B, Hough, M, Myhill, A, Quinton, P \& Tyler, TR 2012, 'Why do people comply with the law? Legitimacy and the influence of legal institutions', British Journal of Criminology, vol. 52, no. 6, pp. 1051-1071.

Jackson, J \& Gau, JM 2015, 'Carving up concepts? Differentiating between trust and legitimacy in public attitudes towards legal authority', in E Shockley, T M S Neal, L Pytlik Zillig \& B Bornstein (eds), Interdisciplinary perspectives on trust: towards theoretical and methodological integration, Springer, New York.

Kelman, HC \& Hamilton, VL 1989, Crimes of obedience, Yale, New Haven.

Loughnan, A 2010, 'Understanding the criminal trial: a response to H L Ho', Sydney Law Review, vol. 32, no. 3, p. 536.

Lucas, JR 1980, On justice, Oxford University Press, Clarendon.

Meyerson, D 2015a, 'The moral justification for the right to make full answer and defence', Oxford Journal of Legal Studies, vol. 35, no. 2, pp. 237-265.

Meyerson, D 2015b, 'Why should justice be seen to be done?', Criminal Justice Ethics, vol. 34, no. 1, pp. 64-86.

Murphy, K, Bradford, B \& Jackson, J 2016, 'Motivating compliance behaviour among offenders: procedural justice or deterrence?', Criminal Justice and Behaviour, vol. 43 , no. 1, pp. 102-118.

Nedim, U 2015, 'Juries don't always follow the law', NSW Courts, Sydney Criminal Lawyers, posted 15th March 2015, viewed 17th January 2020, Available at https:/ nswcourts.com.au/articles/juries-dont-always-follow-the-law/

Solum, LB 2004, 'Procedural justice', Southern California Law Review, vol. 78, no. 1 pp. 181-321.

Sunshine, J \& Tyler, TR 2003, 'The role of procedural justice and legitimacy in shaping public support for policing', Law and Society Review, vol. 37, no. 3, pp. 513-48.

Tyler, TR 1990, Why people obey the law, Princeton University Press, Princeton, NJ.

Tyler, TR 2003, 'The role of procedural justice and legitimacy in shaping public support for policing', Law and Society Review, vol. 37, no. 3, pp. 513-48.

Tyler, TR 2006, 'Psychological perspectives on legitimacy and legitimation', Annual Review of Psychology, vol. 57, no. 1, pp. 375-400.

Tyler, TR \& Fagan, J 2008, 'Legitimacy and cooperation: why do people help the police fight crime in their communities?', Ohio State Journal of Criminal Law, vol. 6 , no. 1, pp. 231-75.

Tyler, TR \& Jackson, J 2013, 'Future challenges in the study of legitimacy and criminal justice', in J Tankebe and A Liebling (eds), Legitimacy and criminal justice, Oxford University Press, Clarendon.

Tyler, TR \& Jackson, J 2014, 'Popular legitimacy and the exercise of legal authority: motivating compliance, cooperation, and engagement', Psychology, Public Policy, and Law, vol. 20, no. 1, pp. 78-95.

Waldron, J 2001, Law and disagreement, Oxford University Press, Clarendon.

Waldron, J 2011, 'The rule of law and the importance of procedure', Nomos, vol. 50, no. 1, pp. 3-31. 